\title{
PENGARUH GROWTH OPPORTUNITY TERHADAP NILAI PERUSAHAAN MELALUI STRUKTUR MODAL (pada Perusahaan Sektor Property, Real Estate \& Building Construction yang Terdaftar di Bursa Efek Indonesia Tahun 2011-2014)
}

\author{
Nova Adhitya Ananda ${ }^{1}$, I Nyoman Nugraha AP $^{2}$ \\ ${ }^{1}$ Program Magister Manajemen Universitas Mataram, novadhitva@gmail.com \\ ${ }^{2}$ Fakultas Ekonomi dan Bisnis Universitas Mataram, ibobid@yahoo.com
}

\begin{abstract}
The purpose of this research is to find the influence of growth opportunity and capital structure on firm value. The research objects used is property, real estate and building construction company which listed in Indonesian Stock Exchange in 2011-2014. This research used a purposive sampling technique in determining the research sample. The number of companies chosen as the sample in 37 company of 54 companies registered in property, real estate and building construction sector. This research was included in the explanatory research using quantitative approach. Data analysis method used in this research is partial least square (PLS) analysis. The result showed that in directly growth opportunity and capital structure has a significant effect on firm value. Growth opportunity undirectly has significant effect on the firm value by means of capital structure. Growth opportunity has a positive and significant effect on capital structure and capital structure has a negative and significant effect on firm value.
\end{abstract}

Keywords : Growth Opportunity, Capital Structure and Firm Value

\begin{abstract}
ABSTRAK
Tujuan penelitian ini adalah untuk mengetahui pengaruh dari growth opportunity dan struktur modal terhadap nilai perusahaan. Objek penelitian yang digunakan adalah perusahaan sektor property, real estate and building construction yang terdaftar di Bursa Efek Indonesia pada tahun 2011-2014. Penelitian ini menggunakan teknik purposive sampling dalam penentuan sampel penelitian. Jumlah perusahaan yang terpilih sebagai sampel penelitian adalah 37 perusahaan dari 54 perusahaan yang terdaftar pada sektor property, real estate and building construction. Penelitian ini termasuk dalam jenis penelitian explanatory research dengan menggunakan pendekatan kuantitatif. Metode analisis data yang digunakan dalam penelitian ini adalah analisis partial least square (PLS). Hasil penelitian menunjukkan bahwa secara langsung growth opportunity dan struktur modal memiliki pengaruh yang signifikan terhadap nilai perusahaan. Growth opportunity berpengaruh secara tidak langsung terhadap nilai perusahaan melalui struktur modal. Growth opportunity berpengaruh positif terhadap struktur modal dan struktur modal berpengaruh negatif terhadap nilai perusahaan.
\end{abstract}

Kata Kunci : Growth Opportunity, Struktur Modal dan Nilai Perusahaan. 


\section{PENDAHULUAN}

\section{Latar Belakang}

Perusahaan didirikan dengan tujuan dan sasaran tertentu. Namun tujuan utama perusahaan adalah kemakmuran pemegang saham yang dicapai melalui peningkatan nilai perusahaan. Nilai perusahaan sendiri ditentukan oleh keputusan investasi. Investasi adalah kegiatan yang dilakukan dengan cara menanamkan dana pada saat ini dengan harapan untuk mendapatkan keuntungan di masa depan. Bentuk investasi yang dimaksud adalah investasi yang dilakukan pada aset nyata dan aset finansial (Ang, 1997).

Nilai perusahaan merupakan persepsi investor terhadap perusahaan, yang sering dikaitkan dengan harga saham. Harga saham tinggi membuat nilai perusahaan juga tinggi. Nilai perusahaan sangat penting karena dengan nilai perusahaan yang tinggi akan diikuti oleh tingginya kemakmuran pemegang saham (Brigham \& Houston, 2013). Kemakmuran pemegang saham dicerminkan oleh harga pasar dari saham yang merupakan cerminan dari keputusan investasi, pendanaan dan manajemen aset. Beberapa faktor yang dapat mempengaruhi nilai perusahaan diantaranya growth opportunity dan struktur modal (Hermuningsih, 2013).

Growth opportunity adalah peluang pertumbuhan suatu perusahaan di masa depan dan merupakan kesempatan perusahaan untuk melakukan investasi pada hal-hal yang menguntungkan perusahaan (Setyawan, Topowijono, \& Nuzula, 2016). Pertumbuhan perusahaan akan membuat investor tertarik terhadap perusahaan karena pertumbuhan perusahaan merupakan tanda bahwa perusahaan memiliki prospek yang menguntungkan di masa depan, sehingga investor mengharapkan akan mendapatkan rate of return atas investasi yang mereka tanamkan.

Kesempatan investasi merupakan nilai perusahaan yang besarnya tergantung pada pengeluaran-pengeluaran yang ditetapkan manajemen di masa yang akan datang, dalam hal ini merupakan pilihan-pilihan investasi yang diharapkan akan menghasilkan keuntungan yang lebih besar (Gaver \& Gaver, 1993). Dalam penelitian ini, growth opportunity diukur menggunakan invesment opportunity set (IOS).

Model informasi asimetris dari William (1988) dan teori aliran kas bebas dari jensen (1986) menyediakan suatu dasar bahwa ada hubungan antara pertumbuhan perusahaan dengan harga saham perusahaan. Kedua-duanya memprediksi bahwa perubahan harga saham merupakan respon dari informasi pertumbuhan perusahaan. Perusahaan yang tumbuh yaitu perusahaan yang memiliki peluang tumbuh yang tinggi, diprediksi mempunyai hubungan yang positif terhadap harga saham sementara untuk perusahaan yang tidak tumbuh atau perusahaan yang memiliki pertumbuhan yang terbatas, diprediksi mempunyai hubungan yang negatif dengan harga saham perusahaan.

Penelitian yang dilakukan oleh Puteri dan Rohman (2012) mengatakan bahwa invesment opportunity set (IOS) berpengaruh positif dan signifikan terhadap nilai perusahaan. sedangkan Hamid (dalam Safitri dan Wahyuati, 2015) mengatakan invesment opportunity set (IOS) berpengaruh positif dan tidak signifikan terhadap nilai perusahaan.

Perusahaan dengan growth opportunity tinggi akan membutuhkan dana yang besar. Peluang pertumbuhan yang tinggi pada dasarnya merupakan suatu harapan yang diinginkan oleh pihak internal perusahaan maupun investor dan kreditor. Peluang pertumbuhan yang tinggi mencerminkan produktivitas perusahaan. Pada sisi yang lain, biaya penerbitan saham lebih mahal daripada penerbitan surat hutang sehingga ini menjadi alasan perusahaan dengan pertumbuhan tinggi lebih menggunakan hutang dalam struktur modal perusahaan. Penggunaan hutang akan menempatkan perusahaan 
dan manajer dalam pengawasan pihak eksternal. Hal ini dapat mencegah manajer untuk berinvestasi pada proyek dengan NPV negatif. Disisi lain, perusahaan dengan growth oportunity tinggi cenderung membelanjai pengeluaran investasi dengan modal sendiri untuk menghindari masalah underinvesment yaitu tidak dilaksanakannya semua proyek investasi yang bernilai positif oleh pihak manajer perusahaan (Chen, 2002).

Penelitian yang dilakukan oleh Hermuningsih (2013) mengatakan bahwa growth opportunity berpengaruh positif dan signifikan terhadap struktur modal, artinya kebijakan penggunaan hutang dapat membantu penggunaan dana kas bebas secara berlebihan oleh pihak manajemen. Penggunaan hutang juga dapat menjadi sinyal positif bagi investor. Sedangkan Setyawan, Topowijono, dan Nuzula (2016) mengatakan bahwa growth opportunity berpengaruh negatif dan signifikan terhadap struktur modal.

Kebijakan hutang dan struktur kepemilikan modal juga dapat mempengaruhi nilai perusahaan dengan adanya pajak, biaya keagenan, dan biaya kesulitan keuangan sebagai imbangan dari manfaat penggunanaan hutang. Menurut tradeoff teori, hutang bermanfaat bagi perusahaan karena bunga dapat dikurangkan dalam menghitung pajak, tetapi hutang juga menimbulkan biaya yang berhubungan dengan kebangkrutan. Struktur modal yang optimal berada pada keseimbangan antara manfaat pajak atas penggunaan hutang dengan biaya yang berhubungan dengan kebangkrutan, karena biaya dan manfaat akan saling meniadakan satu sama lain. Pada tingkat hutang yang optimal diharapkan nilai perusahaan akan mencapai nilai optimal, dan sebaliknya apabila terjadi tingkat perubahan hutang sampai melewati tingkat optimal atau biaya kebangkrutan, hutang akan mempunyai efek negatif terhadap nilai perusahaan.

Penelitian yang dilakukan oleh Moniaga (2013) menemukan bahwa struktur modal berpengaruh signifikan terhadap nilai perusahaan sedangkan Prasetia, Tommy dan Saerang (2014) menemukan bahwa struktur modal tidak berpengaruh signifikan terhadap nilai perusahaan.

Bisnis property dan real estate saat ini dimata masyarakat dinilai sangat menjanjikan karena harga property di Indonesia selalu meningkat setiap tahunnya. Peningkatan ini terjadi akibat PDB per kapita Indonesia dari tahun 2010 sampai dengan tahun 2013 terus naik (www.bps.go.id). Peningkatan ini mengindikasikan bahwa semakin banya orang Indonesia yang mampu membeli properti. Ini berarti permintaan akan rumah, apartemen dan kondominium akan semakin meningkat di masa mendatang. Pertumbuhan ini juga dapat menyebabkan perusahaan property, real estate and building construction akan semakin bertumbuh. Pengelolaan sumber modal melalui komposisi struktur modal yang optimal akan mempengaruhi nilai perusahaan.

Berdasarkan penelitian-penelitian sebelumnya serta fenomena-fenomena yang terjadi di sektor property, real estate and building costruction, maka tujuan penelitian ini adalah untuk mengetahui pengaruh langsung variabel growth opportunity dan struktur modal terhadap nilai perusahaan. serta pengaruh tidak langsung growth opportunity terhadap nilai perusahaan melalui struktur modal.

\section{Teori}

\section{Nilai Perusahaan}

Perusahaan adalah suatu organisasi yang mengkombinasikan dan mengorganisasikan berbagai sumber daya dengan tujuan untuk memproduksi barang dan atau jasa untuk dijual (Salvatore, 2005). Perusahaan ada karena akan menjadi sangat tidak efisien dan mahal bagi pengusaha untuk masuk dan membuat kontrak dengan pekerja dan para pemilik modal, tanah dan sumber daya lain untuk setiap tahap 
produksi dan distribusi yang terpisah. Sebaliknya, pengusaha biasanya masuk dalam kontrak yang besar dan berjangka panjang dengan tenaga kerja untuk mengerjakan berbagai tugas dengan upah tertentu dan berbagai tunjangan lain. Kontrak yang umum semacam itu jauh lebih murah ketimbang sejumlah kontrak spesifik dan sangat menguntungkan baik bagi pengusaha maupun pekerja dan pemilik sumber daya lain. Perusahaan ada karena untuk menghemat biaya transaksi semacam itu. Dengan menginternalisasi berbagai transaksi (yaitu dengan menjalankan berbagai fungsi dalam perusahaan), perusahaan juga menghemat pajak penjualan dan menghindari kontrol harga dan peraturan pemerintah yang berlaku hanya untuk transaksi antar perusahaan.

Nilai perusahaan dapat didefinisikan sebagai nilai wajar perusahaan yang menggambarkan persepsi investor terhadap emiten bersangkutan. Menurut Husnan dan Pudjiastuti (2006), nilai perusahaan merupakan harga yang bersedia dibayar oleh calon pembeli apabila perusahaan tersebut dijual. Sedangkan menurut Keown, et al. (2007) nilai perusahaan merupakan nilai pasar atas surat berharga hutang dan ekuitas perusahaan yang beredar. Harga yang bersedia dibayar oleh calon pembeli diartikan sebagai harga pasar atas perusahaan itu sendiri. Di bursa saham, harga pasar berarti harga yang bersedia dibayar oleh investor untuk setiap lembar saham perusahaan. Oleh karenanya dapat dikatakan bahwa nilai perusahaan adalah merupakan persepsi investor terhadap perusahaan yang selalu dikaitkan dengan harga saham.

Salah satu alternatif yang digunakan dalam menilai nilai perusahaan adalah dengan menggunakan Tobin's q. Menurut Sukamulja (dalam hermuningsih, 2012), rasio ini dinilai bisa memberikan informasi paling baik, karena dalam Tobin's q memasukkan semua unsur hutang dan modal saham perusahaan, tidak hanya saham biasa saja dan tidak hanya ekuitas perusahaan yang dimasukkan namun seluruh aset perusahaan. Dengan memasukkan seluruh aset perusahaan berarti perusahaan tidak hanya terfokus pada satu tipe investor saja yaitu investor dalam bentuk saham namun juga untuk kreditor karena sumber pembiayaan operasional perusahaan bukan hanya dari ekuitasnya saja tetapi juga dari pinjaman yang diberikan oleh kreditor.

\section{Struktur Modal}

Sumber daya keuangan dasar perusahaan adalah aliran kas yang dihasilkan oleh aset/aktiva dan operasinya. Ketika perusahaan didanai seluruhnya oleh saham biasa, semua arus kas itu menjadi milik pemegang saham. Ketika perusahaan menerbitkan utang dan ekuitas sekaligus, perusahaan memecah arus kas menjadi dua aliran, aliran yang relatif aman yang menuju pemegang utang dan aliran yang lebih beresiko yang menuju pemegang saham. Bauran sekuritas perusahaan disebut struktur modalnya (Brealey, Myers, \& Marcus, 2012). Struktur modal merupakan bauran (proporsi) pendanaan permanen jangka panjang perusahaan yang diwakili oleh utang, saham preferen, dan ekuitas saham biasa (Horne \& Wachowicz, 2010) .Per definisi, struktur modal merupakan kombinasi hutang dan ekuitas dalam struktur keuangan jangka panjang perusahaan.

Menurut Brigham dan Houston, (2013) ada beberapa faktor yang mempengaruhi struktur modal; pertama adalah stabilitas penjualan; perusahaan dengan penjualan yang relatif stabil dapat lebih aman memperoleh lebih banyak pinjaman dan menanggung beban tetap yang lebih tinggi dibandingkan dengan perusahaan yang penjualannya tidak stabil. Kedua adalah struktur aktiva; perusahaan yang aktivanya sesuai untuk dijadikan jaminan kredit cenderung lebih banyak menggunakan utang. Faktor ketiga yang mempengaruhi struktur modal adalah leverage operasi. Dalam hal ini, perusahaan dengan leverage operasi yang lebih kecil cenderung lebih mampu untuk memperbesar leverage keuangan karena memiliki resiko bisnis yang lebih kecil. Faktor keempat 
adalah tingkat pertumbuhan; perusahaan yang tumbuh dengan pesat harus lebih banyak mengandalkan modal eksternal. Namun, pada saat yang sama perusahaan yang memiliki pertumbuhan yang pesat sering menghadapi ketidakpastian yang lebih besar, yang cenderung mengurangi keinginannya untuk menggunakan hutang. Struktur modal adalah perimbangan atau perbandingan antara jumlah hutang jangka panjang dengan modal sendiri. Oleh karena itu, struktur modal diukur dengan debt to equity ratio (DER). DER merupakan rasio yang digunakan untuk mengukur tingkat leverage (penggunaan hutang) terhadap total shareholder's equity yang dimiliki perusahaan.

\section{Growth Opportunity}

Growth opportunity adalah peluang pertumbuhan suatu perusahaan di masa depan (Mai dalam Hermuningsih,2013) Definisi lain peluang pertumbuhan adalah perubahan total aktiva yang dimiliki perusahaan. Besaran ini mengukur sejauh mana laba per lembar saham suatu perusahaan dapat ditingkatkan oleh leverage. Perusahaanperusahaan yang memiliki pertumbuhan yang cepat seringkali harus meningkatkan aktiva tetapnya. Growth Opportunity tidak bisa diamati secara langsung oleh pihak luar. Beberapa studi yang dilakukan dalam hubungannya dengan keputusan investasi salah satunya adalah Investment Opportunities Set (IOS) yang dikenalkan oleh Myers pada tahun 1977.

IOS memberi petunjuk yang lebih luas dimana nilai perusahaan tergantung pada pengeluaran perusahaan di masa yang akan datang, dimana pada saat ini merupakan pilihan-pilihan investasi yang diharapkan akan menghasilkan return yang besar. IOS tidak bisa diobservasi secara langsung, sehingga dalam perhitungannya menggunakan proksi. Proksi IOS yang dimaksud adalah proksi sebagaimana yang digunakan oleh Kumalahadi (dalam Hermuningsih,2012) dengan menggunakan salah satu dari 6 (enam) variabel yaitu dengan menggunakan ratio market to book total equity (MTBE).

\section{Hipotesis}

Pengeluaran investasi memberikan sinyal positif tentang pertumbuhan perusahaan dimasa yang akan datang, sehingga meningkatkan harga saham sebagai indikator peningkatan nilai perusahaan. Penelitian yang dilakukan oleh Puteri dan Rohman (2012) mengatakan bahwa investment opportunity set berpengaruh positif dan signifikan terhadap nilai perusahaan. sehingga hipotesis pertama yang akan diuji dalam penelitian ini adalah growth opportunity berpengaruh positif terhadap nilai perusahaan.

Perusahaan dengan growth opportunity tinggi akan membutuhkan dana yang besar. Perusahaan dengan pertumbuhan yang tinggi akan cenderung menggunakan hutang dalam struktur modal perusahaan. Penelitian yang dilakukan oleh Hermuningsih (2013) mengatakan bahwa growth opportunity berpengaruh positif dan signifikan terhadap struktur modal. Hipotesis kedua yang akan diuji dalam penelitian ini adalah growth opportunity berpengaruh positif terhadap struktur modal.

Hutang bermanfaat bagi perusahaan karena bunga dapat dikurangkan dalam menghitung pajak, tetapi hutang juga menimbulkan biaya yang berhubungan dengan kebangkrutan. Struktur modal yang optimal berada pada keseimbangan antara manfaat pajak atas penggunaan hutang dengan biaya yang berhubungan dengan kebangkrutan, karena biaya dan manfaat akan saling meniadakan satu sama lain. Pada tingkat hutang yang optimal diharapkan nilai perusahaan akan mencapai nilai optimal, dan sebaliknya apabila terjadi tingkat perubahan hutang sampai melewati tingkat optimal atau biaya kebangkrutan, hutang akan mempunyai efek negatif terhadap nilai perusahaan. Dalam tataran empiris, Safitri dan Wahyuati (2015) menemukan bahwa struktur modal berpengaruh positif terhadap nilai perusahan. Hipotesis ketiga yang akan diuji dalam 
penelitian ini adalah struktur modal berpengaruh positif terhadap nilai perusahaan. dan hipotesis keempat yang akan diuji adalah growth opportunity bepengaruh terhadap nilai perusahaan melalui struktur modal.

\section{METODE PENELITIAN}

\section{Populasi dan Sampel}

Populasi dalam penelitian ini adalah 54 perusahaan property, real estate \& building construction yang terdaftar di Bursa Efek Indonesia pada Periode 2011 - 2014. Sampel adalah bagian dari jumlah dan karakteristik yang dimiliki oleh populasi tersebut. Bila populasi besar dan peneliti tidak mungkin mempelajari semua yang ada pada populasi, misalnya karena keterbatasan dana, tenaga dan waktu, maka peneliti dapat menggunakan sampel yang diambil dari populasi itu. Apa yang dipelajari dari sampel itu, kesimpulannya akan dapat diberlakukan untuk populasi (Sugiyono, 2010). Metode pengambilan sampel pada penelitian ini menggunakan purposive sampling yaitu teknik pemilihan sampel ketika peneliti tidak memiliki data tentang populasi dalam bentuk sampling frame dan peneliti kemudian memilih sampel berdasarkan kriteriakriteria tertentu dan penilaian peneliti untuk mengarahkan sampel terpilih sesuai dengan tujuan penelitian (Abdillah \& Jogiyanto, 2015).

\section{Sumber dan Teknik Pengumpulan Data}

Data dalam penelitian ini merupakan data sekunder. Data sekunder adalah data yang diperoleh melalui atau berasal dari pihak kedua yang ikut mengetahui atau memiliki suatu data (Abdillah \& Jogiyanto, 2015). Data yang pengumpulan dan pengolahannya dilakukan oleh pihak lain yang didapat dari ICMD (Indonesian Capital Market Directory) dan website : www.idx.co.id berupa laporan keuangan perusahaanperusahaan property, real estate \& building construction yang listing di Bursa Efek Indonesia periode 2011-2014.

Teknik pengumpulan data yang digunakan dalam penelitian ini adalah teknik dokumentasi. Teknik dokumentasi adalah teknik yang dilakukan dengan cara mempelajari atau menyalin catatan atau dokumen yang berhubungan dengan data yang dikumpulkan. Data didapat dari ICMD (Indonesian Capital Market Directory) dan website : www.idx.go.id berupa laporan keuangan perusahaan-perusahaan property, real estate \& building construction yang listing di Bursa Efek Indonesia periode 20112014.

\section{Definisi Operasional Variabel}

Variabel dalam penelitian ini adalah variabel eksogen dan variabel endogen. Variabel-variabel eksogen dalam model jalur ialah semua variabel yang tidak ada penyebab-penyebab eksplisitnya atau dalam diagram tidak ada anak-anak panah menuju ke arahnya, atau dengan kata lain adalah variabel yang tidak diprediksi oleh variabel lainnya (Sarwono \& Suhayati, 2010). Dalam penelitian ini yang dijadikan variabel eksogen adalah: Growth Opportunity (X1) dan variabel intervening adalah Struktur Modal (X2). Variabel endogen adalah variabel yang diprediksi oleh satu atau beberapa variabel eksogen. Dalam penelitian ini yang menjadi variabel endogen adalah nilai perusahaan (Y).

Nilai perusahaan diukur dengan Tobins'q, yang merupakan rasio nilai pasar saham perusahaan terhadap nilai buku ekuitas perusahaan. Formulanya adalah:

$$
Q=\frac{(E M V+D)}{\left(E M B^{i}+D\right)}
$$


Dimana $\mathrm{Q}=$ nilai perusahaan ; $\mathrm{D}=$ nilai buku dari total hutang ; $\mathrm{EMV}=$ nilai pasar dari ekuitas ; dan EBV = nilai buku dari ekuitas. EMV (equity market value) diperoleh dari hasil perkalian harga saham penutupan dengan jumlah saham yang beredar. EBV (equity book value) diperoleh dari selisih total aset dengan total kewajiban.

Pertumbuhan perusahaan diukur dengan menggunakan Investment Opportunity Set (IOS). IOS adalah komponen nilai perusahaan yang berasal dari pilihan melakukan investasi di masa yang akan datang (Myers. 1977). Dalam penelitian ini menggunakan rasio nilai pasar ekuitas terhadap nilai bukunya / Market to Books Total Equity (MTBE) Formulanya adalah sebagai berikut :

$$
M T B E=\frac{\text { Jumlah Lembar saham yang beredar } x \text { harga saham }}{\text { Total ekuitas }}
$$

Struktur modal diukur dengan debt to equity ratio (DER) adalah perbandingan total hutang yang dimiliki perusahaan dengan total ekuitas perusahaan pada perusahaan property, real estate \& building construction di BEI Tahun 2011-2014. Formulanya sebagai berikut :

$$
\text { DER }=\frac{\text { Total Hutang }}{\text { Total Ekuitas }} x 100 \%
$$

\section{Teknik Analisis Data}

Penelitian ini menggunakan teknik analisis partial least square (PLS) dan untuk menguji hubungan linier dari variabel yang diteliti menggunakan uji linieritas. Uji linieritas adalah suatu prosedur yang digunakan untuk mengetahui status linier tidaknya suatu distribusi data penelitian. Uji linieritas dilakukan untuk membuktikan bahwa masing-masing variabel bebas mempunyai hubungan yang linier dengan variabel terikat.

Baik korelasi maupun regresi linier dibangun berdasarkan asumsi bahwa variabel-variabel yang dianalisis memiliki hubungan linier. Pengujian linearitas ini perlu dilakukan, untuk mengetahui model yang dibuktikan merupakan model linear atau tidak. Uji linieritas dilakukan dengan menggunakan curve estimation, yaitu gambaran hubungan linier antara variabel eksogen dengan variabel endogen. Jika nilai $s i g<0,05$, maka variabel eksogen tersebut memiliki hubungan linier dengan endogen. Kalau dalam pengujian ini diperoleh $\operatorname{sig}>0,05$ ( $\alpha$ 5\%) berarti tidak signifikan.

Menurut Ghozali (2014) tujuan PLS adalah membantu peneliti untuk mendapatkan nilai variabel laten untuk tujuan prediksi. Variabel laten adalah linear agregat dari indikator-indikatornya. Weight estimate untuk menciptakan komponen skor variabel laten didapat berdasarkan bagaimana inner model (model struktural yang menghubungkan antar variabel laten dan outer model (model pengukuran yaitu hubungan antara indikator dengan konstruknya) dispesifikasi. Hasilnya adalah residual variance dari variabel independen (keduanya variabel laten dan indikator) diminimumkan.

Dalam penelitian ini, model struktural yang dianalisis memenuhi model formatif dengan semua indikator dari dua variabel eksogen yaitu Growth Opportunity (X1), dan Struktur Modal (X2) dan variabel endogen yaitu Nilai Perusahaan (Y). Pengujian hipotesis dilakukan dengan partial least square (PLS). Kalau dalam pengujian ini diperoleh $p$-value $<0,05(\alpha$ 5\%) atau nilai t-statistik $>$ t-tabel, berarti pengujian signifikan, dan sebaliknya kalau $p$-value $>0,05$ ( $\alpha$ 5\%) atau t-statistik $<\mathrm{t}$-tabel, berarti tidak signifikan. Bilamana hasil pengujian hipotesis pada outer model signifikan, hal ini menunjukkan bahwa indikator dipandang dapat digunakan sebagai instrumen pengukur 
variabel laten. Sementara, bilamana hasil pengujian pada inner model adalah signifikan, maka dapat diartikan bahwa terdapat pengaruh yang bermakna variabel laten satu terhadap variabel laten lainnya.

\section{PEMBAHASAN}

\section{Pengujian Linieritas dan Partial Least Square (PLS)}

Penelitian ini melakukan uji linieritas terhadap model penelitian untuk mengetahui apakah terhadap hubungan linier antara growth opportunity dengan struktur modal, growth opportunity dengan nilai perusahaan dan struktur modal dengan nilai perusahaan. Untuk uji linieritas ini digunakan pendekatan dengan curve estimation, jika salah satu saja dari hasil output uji tersebut signifikan, maka dapat dikatakan bahwa hubungan variabel eksogen dengan endogen tersebut linier. Ringkasan hasil uji linieritas terhadap model dengan menggunakan curve estimation adalah sebagai berikut :

Tabel 1. Uji Linieritas

\begin{tabular}{|l|c|c|c|}
\hline \multirow{2}{*}{ Sig. } & \multicolumn{3}{|c|}{ Hubungan } \\
\cline { 2 - 4 } & $\begin{array}{c}\text { MTBE dengan } \\
\text { DER }\end{array}$ & $\begin{array}{c}\text { MTBE dengan } \\
\text { TOBIN'Q }\end{array}$ & $\begin{array}{c}\text { DER dengan } \\
\text { TOBIN'Q }\end{array}$ \\
\hline Linear & 0,000 & 0,000 & 0,219 \\
\hline Logarithmic ${ }^{\mathrm{a}}$ & 0,000 & 0,000 & 0,530 \\
\hline Inverse & 0,594 & 0,420 & 0,002 \\
\hline Quadratic & 0,000 & 0,000 & 0,455 \\
\hline Cubic & 0,000 & 0,000 & 0,372 \\
\hline Compound & 0,036 & 0,000 & 0,000 \\
\hline Power ${ }^{\mathrm{a}}$ & 0,001 & 0,000 & 0,000 \\
\hline S & 0,686 & 0,156 & 0,289 \\
\hline Growth & 0,036 & 0,000 & 0,000 \\
\hline Exponential & 0,036 & 0,000 & 0,000 \\
\hline Logistic & 0,036 & 0,000 & 0,000 \\
\hline
\end{tabular}

Sumber : data diolah

Dari tabel 1 diatas dapat disimpulkan bahwa terdapat hubungan linier dari model penelitian. Ini terbukti dari hasil pengujian yang menunjukan hasil signifikan $(<0,05)$ pada salah satu alat yang digunakan untuk menguji hubungan antara variabel eksogen dengan variabel endogen.

PLS sebagai model prediksi tidak mengasumsikan distribusi tertentu untuk mengestimasi parameter dan memprediksi hubungan kausalitas. Karena itu, teknik parametrik untuk menguji signifikansi parameter tidak diperlukan dan model evaluasi untuk prediksi bersifat non parametrik. Model evaluasi PLS berdasarkan pada pengukuran prediksi yang mempunyai sifat non-parametrik. Oleh karena itu, model evaluasi PLS dilakukan dengan menilai outer model dan inner model. 


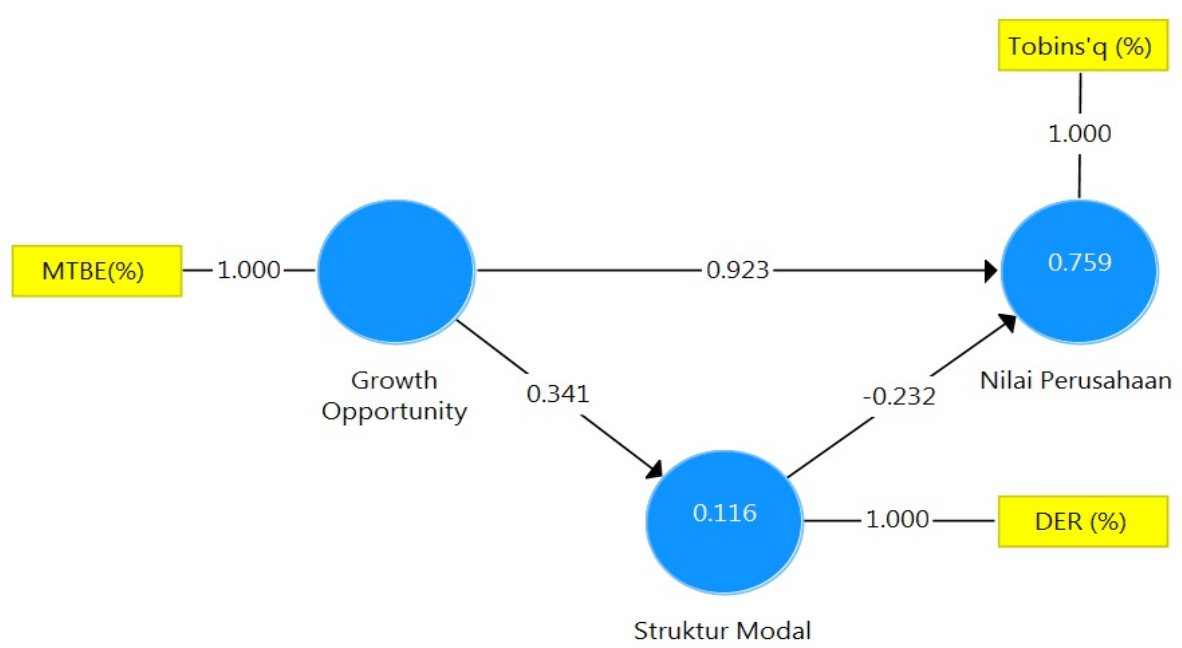

Gambar 1. Diagram Jalur Hasil Output SmartPLS 3.0

Tabel 2. R Square

\begin{tabular}{|l|r|r|}
\hline & R Square & R Square Adjusted \\
\hline Nilai Perusahaan & 0.759 & 0.756 \\
\hline Struktur Modal & 0.116 & 0.110 \\
\hline
\end{tabular}

Sumber : data diolah

Tabel 2 diatas menjelaskan bahwa nilai $R$-square sebesar 0,116 berarti model regresi memiliki tingkat goodness of fit yang lemah, artinya variabilitas struktur modal yang dapat dijelaskan oleh variabel growth opportunity sebesar $11,6 \%$ sedangkan $88,4 \%$ dijelaskan oleh variabel lain diluar model atau penelitian ini. Sementara nilai $R$ square sebesar 0,759 atau $75,9 \%$ nilai perusahaan dipengaruhi oleh growth opportunity dan struktur modal sedangkan $24,1 \%$ yang mempengaruhi nilai perusahaan berasal dari variabel lain diluar penelitian.

Q-Square predictive relevance untuk model penelitian ini dapat dihitung dengan rumus sebagai berikut :

$$
\begin{aligned}
\mathrm{Q}^{2} & =1-\left(1-\mathrm{R}_{1}^{2}\right)\left(1-\mathrm{R}_{2}^{2}\right) \\
& =1-(1-0.116)(1-0.759) \\
& =1-(0.884)(0.241) \\
& =1-0.213 \\
& =0.787(78.7 \%)
\end{aligned}
$$

Dari hasil perhitugan Q Square diatas dapat diartikan bahwa koefisien determinasi dari model sebesar $78.7 \%$. Berarti model memiliki tingkat goodness fit yang baik yang berarti variabilitas nilai perusahaan yang dapat dijelaskan oleh kedua variabel dalam model sebesar $78.7 \%$ sedangkan $21.3 \%$ dijelaskan oleh variabel lain yang tidak diteliti dalam model ini. 
Tabel 3. Path Coefficients

\begin{tabular}{|l|r|r|r|r|r|}
\hline & $\begin{array}{c}\text { Original } \\
\text { Sample } \\
(\mathbf{O})\end{array}$ & $\begin{array}{c}\text { Sample } \\
\text { Mean } \\
\text { (M) }\end{array}$ & $\begin{array}{c}\text { Standard } \\
\text { Deviation } \\
\text { (STDEV) }\end{array}$ & $\begin{array}{r}\text { T Statistics } \\
(\text { (O/STDEV|) }\end{array}$ & P Values \\
\hline $\begin{array}{l}\text { Growth Opportunity }> \\
\text { Nilai Perusahaan }\end{array}$ & 0.923 & 0.928 & 0.041 & 22.434 & 0.000 \\
\hline $\begin{array}{l}\text { Growth Opportunity }> \\
\text { Struktur Modal }\end{array}$ & 0.341 & 0.350 & 0.123 & 2.771 & 0.003 \\
\hline $\begin{array}{l}\text { Struktur Modal > Nilai } \\
\text { Perusahaan }\end{array}$ & -0.232 & -0.216 & 0.073 & 3.165 & 0.001 \\
\hline
\end{tabular}

Sumber : data diolah

Berdasarkan tabel 3 dapat disimpulkan bahwa growth opportunity berpengaruh langsung terhadap nilai perusahaan dengan koefisien sebesar 0,923 dan juga dapat dikatakan signifikan dimana nilai $\mathrm{t}$ hitung $(22,434)>\mathrm{t}$ tabel $(1,976)$. Growth opportunity berpengaruh langsung terhadap struktur modal dimana $t$ hitung $(2,771)>t$ tabel $(1,976)$ dengan koefisien sebesar 0,341 . Struktur modal berpengaruh terhadap nilai perusahaan dimana $t$ hitung $(3,165)>t$ tabel $(1,976)$.

Berdasarkan tabel 3 dapat menjawab hipotesis penelitian. Hipotesis pertama yang menyatakan growth opportunity berpengaruh positif terhadap nilai perusahaan diterima. Hipotesis kedua yang menyatakan growth opportunity berpengaruh positif terhadap struktur modal diterima. Hipotesis ketiga yang menyatakan bahwa struktur modal berpengaruh positif terhadap nilai perusahaan ditolak. Hasil penelitian menunjukan bahwa struktur modal berpengaruh negatif dan signifikan terhadap nilai perusahaan.

Mengacu pada model penelitian yang dibuat, terdapat 2 (dua) variabel yang berpengaruh secara langsung terhadap nilai perusahaan yaitu growth opportunity, dan struktur modal. Sebagaimana disebutkan sebelumnya, struktur modal dipengaruhi oleh variabel growth opportunity. Jika growth opportunity berpengaruh signifikan terhadap struktur modal, maka tinggal siginifikansi dari struktur modal terhadap nilai perusahaan yang akan menentukan apakah struktur modal dapat berfungsi sebagai intervening variable dalam menjembatani pengaruh tidak langsung growth opportunity terhadap nilai perusahaan.

Ulasan sebelumnya telah memastikan bahwa struktur modal secara signifikan berpengaruh terhadap nilai perusahaan, maka tinggal menelusuri apakah growth opportunity signifikan mempengaruhi struktur modal atau tidak. Hasil estimasi model menunjukkan growth opportunity berpengaruh positif dan signifikan terhadap struktur modal. Ini memberikan makna bahwa struktur modal merupakan variabel intervening untuk growth opportunity. Maka hipotesis keempat yang menyatakan bahwa growth opportunity berpengaruh secara tidak langsung terhadap nilai perusahaan melalui struktur modal, diterima.

\section{Pengaruh Growth Opportunity terhadap Nilai Perusahaan}

Kebijakan investasi melalui pemilihan proyek atau kebijakan penciptaan produk baru, penggantian mesin yang lebih efisien, pengembangan research \& development dan merger dengan perusahaan lain merupakan hasil yang diperoleh dari efek langsung keputusan investasi terhadap nilai perusahaan (Fama, 1978).

Growth opportunity yang diukur melalui investment opportunity set dengan proksi MTBE menandakan bahwa pasar menilai return dari investasi perusahaan di masa 
depan akan lebih besar dari return yang diharapkan dari ekuitasnya. Hasil pengujian menunjukan growth opportunity berpengaruh positif dan signifikan terhadap nilai perusahaan. Investor tertarik kepada pertumbuhan perusahaan karena memberikan aspek yang positif dalam arti bahwa dengan adanya pertumbuhan perusahaan merupakan tanda bahwa perusahaan memiliki prospek yang menguntungkan di masa depan dan investor berharap rate of return atas investasi yang mereka tanamkan akan tinggi. Hasil ini sesuai dengan pendapat yang dikemukakan Fama (1978) dan penelitian yang dilakukan oleh Puteri dan Rohman (2012).

\section{Pengaruh Growth Opportunity terhadap Struktur Modal}

Peluang pertumbuhan mencerminkan produktifitas perusahaan dalam melakukan investasi terhadap hal-hal yang dapat mendatangkan keuntungan bagi perusahaan di masa depan. Dalam penelitian ini, growth opportunity diukur menggunakan investment opportunity set (IOS). Invesment opportunity set merupakan nilai perusahaan yang besarnya tergantung pada pengeluaran-pengeluaran yang ditetapkan manajemen di masa yang akan datang, dimana pada saat ini merupakan pilihan-pilihan investasi yang diharapkan akan menghasilkan return yang besar (Gaver \& Gaver, 1993). IOS tidak dapat diobservasi secara langsung sehingga dalam perhitungannya menggunakan proksi. Proksi yang digunakan yaitu market to books total equity (MTBE). Perusahaan yang mempunyai ratio MTBE yang tinggi memiliki pertumbuhan aktiva dan ekuitas yang besar.

Dalam penelitian ini, growth opportunity berpengaruh positif terhadap struktur modal, artinya ketika terjadi peningkatan nilai growth opportunity maka dapat meningkatkan struktur modal perusahaan. Hasil penelitian ini sejalan dengan penelitian yang dilakukan oleh Hermuningsih (2013) dan dengan hasil estimasi ini sejalan dengan Brigham dan Houston (2013) menyatakan bahwa perusahaan yang tumbuh dengan pesat cenderung mengandalkan modal eksternal.

\section{Pengaruh Struktur Modal terhadap Nilai Perusahaan}

Trade-off theory menjelaskan bahwa jika posisi struktur modal berada di bawah titik optimal maka setiap penambahan hutang akan meningkatkan nilai perusahaan. Sebaliknya, setiap jika posisi struktur modal berada di atas titik optimal maka setiap penambahan hutang akan menurunkan nilai perusahaan. Dari hasil penelitian ini didapat hasil bahwa struktur modal berpengaruh negatif terhadap nilai perusahaan. Hasil ini sesuai dengan penelitian yang dilakukan oleh Wahyuni, Ernawati dan Murhadi (2013).

Penggunaan hutang yang tinggi akan menyebabkan timbulnya biaya kebangkrutan, biaya keagenan, beban bunga yang semakin besar dan sebagainya. Apabila biaya kebangkrutan semakin besar, tingkat keuntungan yang disyaratkan oleh pemegang saham juga semakin tinggi. Biaya modal hutang juga akan semakin tinggi karena pemberi pinjaman akan membebankan bunga yang tinggi sebagai kompensasi kenaikan risiko kebangkrutan. Oleh karena itu, perusahaan akan terus menggunakan hutang apabila manfaat hutang (penghematan pajak dari hutang) masih lebih besar dibandingkan dengan biaya kebangkrutan. Jika biaya kebangkrutan lebih besar dibandingkan dengan penghematan pajak dari hutang, perusahaan akan menurunkan tingkat hutangnya. 


\section{SIMPULAN}

Growth opportunity berpengaruh positif dan signifikan terhadap nilai perusahaan, artinya bahwa peluang pertumbuhan perusahaan memberikan sinyal positif kepada investor terkait rate of return atas investasi yang mereka tanamkan akan tinggi. Growth opportunity berpengaruh positif dan signifikan terhadap struktur modal. Peningkatan growth opportunity yang diukur melalui investment opportunity set dengan proksi MTBE memberikan makna bahwa nilai pasar perusahaan lebih tinggi daripada nilai ekuitasnya. Meningkatnya ratio MTBE mencerminkan produktivitas perusahaan. Penggunaan hutang dapat mendorong manajer untuk lebih hati-hati dalam memilih proyek yang akan memberikan return bagi pemegang saham. Struktur modal berpengaruh negatif dan signifikan terhadap nilai perusahaan, Hal ini berarti bahwa penggunaan hutang perusahaan melebihi batas optimal sehingga berdampak pada penurunan nilai perusahaan akibat dari meningkatnya resiko kebangkrutan akibat dari penggunaan hutang.

Growth opportunity berpengaruh terhadap nilai perusahaan melalui struktur modal, artinya bahwa peningkatan nilai pasar perusahaan menandakan bahwa perusahaan memiliki prospek pertumbuhan dimasa depan akibat dari kebijakan investasi yang dilakukan perusahaan. Perusahaan dengan pertumbuhan tinggi memilih menggunakan hutang dalam struktur modalnya. Penggunaan hutang bemanfaat untuk mencegah manajer perusahaan untuk berinvestasi pada proyek dengan NPV negatif. Penggunaan hutang yang berlebihan atau melebihi titik optimalnya mengakibatkan penurunan nilai perusahaan. penurunan nilai perusahaan terjadi karena resiko yang ditanggung oleh pemegang saham lebih besar dibandingkan dengan tingkat pengembalian yang mungkin akan didapatkan. 


\section{DAFTAR PUSTAKA}

Abdillah, W., \& Jogiyanto. (2015). Partial Least Square (PLS) Alternatif Structural Equation Modelling (SEM) dalam Penelitian Bisnis. Yogyakarta: Penerbit ANDI.

Ang, R. (1997). Buku Pintar Pasar Modal Indonesia. Jakarta: Mediasoft Indonesia.

Brealey, R. A., Myers, S. C., \& Marcus, A. J. (2012). Dasar-Dasar Manajemen Keuangan Perusahaan, Jilid 2. Jakarta: Penerbit Erlangga.

Brigham, E. F., \& Houston, J. F. (2013). Dasar-dasar Manajemen Keuangan, Buku 1 Edisi 11. Jakarta: Penerbit Salemba Empat.

Chen, K. (2002). The Influence of Capital Structure on Company Value with Different Growth Opportunities. Paper presented at the Paper for EFMA 2002 Annual Meeting, FAME and University of Lausanne. www.google.com

Fama, E. F. (1978). The Effect of a Firm's and Financing Decisions on the Welfare of Its Security Holders. The American Economic Review, Vol. 68 No.3(Juni), Hal. $272-284$.

Gaver, J. J., \& Gaver, K. M. (1993). Additional Evidence on The Association Between The Invesment Opportunity Set and Corporate Financing, Dividend, and Compensation Policies. Journal of Accounting and Economics 16, pp. 125-160.

Ghozali, I. (2014). Structural Equation Modelling, Metode Alternatif dengan Partial Least Square (PLS), Edisi 4. Semarang: Badan Penerbit Universitas Diponegoro.

Hermuningsih, S. (2013). Pengaruh Profitabilitas, Growth Opportunity, Struktur Modal terhadap Nilai Perusahaan pada Perusahaan Publik di Indonesia. Buletin Ekonomi Moneter dan Perbankan(Oktober), Hal. 128 - 148.

Horne, J. C. V., \& Wachowicz, J. M. (2010). Prinsip-Prinsip Manajemen Keuangan, Buku 2 Edisi 12. Jakarta: Salemba Empat.

Husnan, S., \& Pudjiastuti, E. (2006). Dasar-Dasar Manajemen Keuangan, Edisi Kelima. Yogyakarta: UPP STIM YKPN.

Moniaga, F. (2013). Struktur Modal, Profitabilitas dan Struktur Biaya terhadap Nilai Perusahaan Industri Kermik, Porcelen dan Kaca Periode 2007-2011. Jurnal EMBA, Vol.1 No.4(Desember), Hal. 433-442.

Prasetia, T. d. E., Tommy, P., \& S.Saerang, I. (2014). Struktur Modal, Ukuran Perusahaan dan Risiko Perusahaan terhadap Nilai Perusahaan Otomotif yang Terdaftar di BEI. Jurnal EMBA, Vol.2 No.2(Juni), Hal. 879-889.

Safitri, N., \& Wahyuati, A. (2015). Pengaruh Struktur Modal dan Keputusan Investasi terhadap Profitabilitas dan Nilai Perusahaan. Jurnal Ilmu dan Riset Manajemen, Volume 4 Nomor 2(Februari).

Salvatore, D. (2005). Ekonomi Manajerial dalam Perekonomian Global. Jakarta: Salemba Empat.

Setyawan, A. I. W., Topowijono, \& Nuzula, N. F. (2016). Pengaruh Firm Size, Growth Opportunity, Profitbility, Business Risk, Effective Tax Rate, Asset Tangibility, 
Firm Age, dan Liquidity terhadap Struktur Modal Perusahaan. (Studi pada Perusahaan Sektor Property dan Real Estate yang Terdaftar di BEI Tahun 20092014). Jurnal Administrasi Bisnis (JAB), Vol.31 No.1(Februari 2016), 108-117.

Sugiyono. (2010). Metode Penelitian Bisnis. Bandung: Alfabeta. 